\title{
Analysis of the prevalence of strategic management accounting techniques and the level of development of the cost system in large companies in Bosnia and Herzegovina
}

\section{Анализа заступљености техника стратешког управљачког рачуноводства и нивоа развијености трошковног система у великим босанскохерцеговачким компанијама}

\author{
Srđan Lalić \\ srdjan.lalic.efb@gmail.com \\ Amra Gadžo \\ University of Tuzla, Faculty of Economics, Bosnia and Herzegovina, amra.gadzo@untz.ba \\ Benina Veledar \\ University of Sarajevo, School of Economics and Business, Bosnia and Herezgovina, \\ benina.veledar@efsa.unsa.ba
}

University of East Sarajevo, Faculty of Economics, Republika Srpska, Bosnia and Herzegovina,

\begin{abstract}
The paper has two research goals. The first goal is to investigate the prevalence of certain techniques of strategic management accounting in large companies in Bosnia and Herzegovina (hereinafter $\mathrm{BiH}$ ), while the second research goal is to analyze the dependence of the number of strategic management accounting techniques used and the degree of development of the cost system in the company. For the purposes of this research, we collected survey questionnaires from 110 large companies based in $\mathrm{BiH}$. The results of the research show that the three most common techniques of strategic management accounting in large companies in $\mathrm{BiH}$ are: Quality Costing (52.73\%), Strategic Pricing (51.82\%) and Benchmarking (50.91\%), while the least common techniques are: Life Cycle Costing (11.82\%), Attribute Costing and Integrated Performance Management Systems (with 12.73\% each), and Activity Based Costing/ Management (17.27\%). One-way analysis of variance (ANOVA) tested the differences in the number of strategic management accounting techniques used and the level of development of the cost system in companies. Companies that applied on average two techniques of strategic management accounting belonged to the first level of development, those that applied on average four techniques belonged to the second level of development, while companies that have the third level of cost system development on average applied six techniques of strategic management accounting. There were no companies in the sample with the fourth and fifth level of development of the cost system.
\end{abstract}

Keywords: strategic management accounting, representation of techniques, level of development of the cost system, Bosnia and Herzegovina

JEL classification: M40, M41

Сажетак: Рад има два циља истраживања. Први циљ је истражити преваленцију одређених техника стратешког управљачког рачуноводства у великим компанијама у Босни и Херцеговини (БиХ). Други циљ 
истраживања је анализирање зависности броја коришћених техника стратешког управљачког рачуноводства и степена развијености трошковног система у предузећу. За потребе овог истраживања прикупљени су анкетни упитници у 110 великих компанија са седиштем у БиХ. Резултати истраживања показују да су три најчешће технике стратешког управљачког рачуноводства у великим компанијама у БиХ: Quality Costing (52,73\%), Strategic Pricing (51,82\%) и Benchmarking (50,91\%), док су најмање уобичајене технике: Life Cycle Costing (11,82\%), Attribute Costing и Integrated Performance Management Systems (са по 12,73\%) и Activity Based Costing/Management (17,27\%). Једносмерном анализом варијансе (AНOBA) тестиране су разлике у броју коришћених техника стратешког управљачког рачуноводства и нивоа развијености трошковног система у компанијама. Компаније које су примењивале у просеку две технике стратешког управљачког рачуноводства припадале су првом степену развоја, оне које су примењивале у просеку четири технике припадале су другом степену развоја, док су у просеку шест техника стратешког управљачког рачуноводства примењивала предузећа која имају трећи ниво развијености трошковног система. У узорку није било предузећа са четвртим и петим нивоом развијености трошковног система.

Кључне речи: стратешко управљачко рачуноводство, заступљеност техника, ниво развијености трошковног система, Босна и Херцеговина

JEЛ класификација: M40, M41

\section{Introduction}

Strategic management was created as a result of the increased interest of management to get to know the external environment in which the company operates. Such a shift in focus from the internal to the external environment has resulted in the emergence, development and refinement of the strategic dimension of governance. Strategic management is achieved through a set of business decisions aimed at long-term management of company profitability. Profitability management is based on the chosen market strategy and the creation of competitive advantages. And for that to happen, a company must be able to know well the internal processes, costs, value chain, and drivers of its performance. That is, in order to realize strategic management, management decisions must be based on relevant and timely accounting information. This part of the accounting activity is known as Strategic Management Accounting (hereinafter SMA). SMA instruments for strategic planning, control and performance measurement, we objectify through strategic business decision making, are based on a number of associated strategic management accounting techniques. The number of adopted techniques of SMA depends primarily on the needs of management, which also forms the backbone of the development of the company's cost system.

\section{Literature review}

SMA is an accounting and organizational solution for the formation of a relatively independent, strategically appropriate, accounting and information database and strategic management calculation aimed at top management of the company, to select, develop, implement, control and change competitive strategies (Janjic, 2006: 113). The official definition of SMA, published in 2005 by the Chartered Institute of Management Accountants (hereinafter CIMA), defines SMA as a form of management accounting in which the emphasis is on information linking external factors to the firm, non-financial information and internally generated information (Drury, 2008: 570). Starting from such an 
understanding of SMA, its market orientation stands out in the foreground. Therefore, in the professional literature there are also alternative names for this part of management accounting, such as market-oriented and market-driven accounting.

A large number of authors have confirmed through their research that companies must adopt various innovative SMA techniques if they are to survive in the market (Simmonds, 1981; Shank, 1989; Bromwich, 1996; Roslender, 1995; Kaplan \& Norton, 1992, and others). Also, a large number of authors have argued that a similar level of enterprise performance can be achieved using different business strategies and different designs of management accounting techniques used (Miles, et al. 1978; Bensaou \& Venkatraman, 1995; Marlin, Ketchen, Lamont, 2007; Short, Payne, Ketchen, 2008). Authors Cinquini and Tenucci (2010) based on a survey conducted on a large sample of companies in Italy confirmed that companies (regardless of the type of business strategy) mostly use management accounting information regarding costs, customers and competition. It was concluded that there are no differences between business strategies and the SMA techniques used, and that the same techniques can support different business approaches of companies.

In their reports to CIMA, Bromwich \& Bhimani (1989; 1994), emphasize the importance of qualitative and non-financial measures for the management of manufacturing enterprises. According to research by Akenbor \& Okoye (2013), SMA improves the competitive advantage of manufacturing companies. The results of the research by Gadžo \& Lalić (2019) confirmed that there is a direct link between the level of development of cost systems of manufacturing companies in the Federation of Bosnia and Herzegovina and the business performance of companies. It is also important to emphasize that the management accounting function in $\mathrm{BiH}$ companies is not sufficiently developed (Puškarević \& Gadžo 2014a, Puškarević \& Gadžo 2014b). According to Milićević (2003: 429), the SMA must make an effort to make life information about the costs and benefits of product attributes, i.e. everything that makes the product attractive to potential customers and to enable the identification of certain functions in the company's value chain which increase the values for the end user who is willing to buy the company's products because of them.

According to research in Croatia, Ramljak \& Rogošić (2012), it has been proven that the implementation of more than one technique provides a better insight into activities that do not add value, which leads to better cost control. The authors conclude that firms looking to increase their market share and profitability rate need to adopt more sophisticated SMA practices.

The CIMA research in the paper "Management Accounting in Support of the Strategic Management Process", resulted in the following most significant conclusions:

- Accounting information is significantly used in the process of making strategic decisions and formulating organizational strategy. However, a large number of respondents stressed that decisions are made not only on the basis of quantitative 
accounting information, but also on the basis of other available information. The most common strategic decisions include decisions about prices, business and market development, new product development, and decisions on mergers and acquisitions.

- The most commonly used management accounting techniques are: target costing, net present value, cost-benefit analysis, benchmarking and customer profitability. At the same time, the most popular technique is the analysis of customer profitability. However, it is not based on an adequate scientific basis. No modern techniques are used to allocate indirect costs to customers. The focus is on customer classification and price difference control. Those who use ABC use it in a simplified measure, only to allocate indirect costs by product. Within benchmarking, the position of companies within the branch of activity, who the competitors are, and the products and prices they offer are mainly measured.

\section{Research objectives}

The first objective of the research is to determine the presence of certain techniques of SMA in large companies in $\mathrm{BiH}$. Here it is necessary to emphasize that the representation of certain techniques of SMA directly depends on the affiliation of the company in the sample to certain industries. Therefore, when forming the research sample, care was taken about the percentage of companies from the production, service and trade activities.

The second research objective is to analyze the dependence of the number of SMA techniques used and the level of development of cost systems for companies. Our goal is to investigate how many SMA techniques are used by companies with different levels of cost system development.

\section{Research methodology}

Research of the prevalence of certain SMA techniques first required the creation of a research sample of large companies separately for the Federation of Bosnia and Herzegovina (hereinafter FBiH) and the Republic of Srpska (hereinafter RS). The reasons are significant inequality in the number of large enterprises by individual structural activities in FBiH and RS. The classification of companies into large ones is based on the currently valid criteria from the Law on Accounting and Auditing of FBiH and RS. Data collection was conducted by survey. Although the number of surveyed legal entities was 168 , due to the need to unify the structure of activities, the final sample consisted of 110 large companies (67 from $\mathrm{FBiH}$ and $43 \mathrm{RS}$ ).

For the purpose of researching the dependence of the application of SMA techniques and the level of development of the cost system of enterprises, we first had to classify enterprises according to the level of development of cost systems. In this process, we relied on a multiphase model of cost systems development set up by Robin Cooper and Robert Kaplan (1991; 1999). Their four-phase model was subsequently upgraded by Gary Cokins (2001). We published a detailed explanation of the methodology for classifying the level of development of the cost system in the paper (Gadžo \& Lalić, 2019). The classification of 
the level of development of the cost system was made on the basis of four criteria: data quality, quality of external financial reporting, structure of cost allocation by cost center and quality of operational/ strategic control (Figure 1).

Figure 1. Classification criteria for cost system development

\begin{tabular}{|c|c|c|c|c|c|}
\hline $\begin{array}{l}\text { System } \\
\text { Aspects }\end{array}$ & $\begin{array}{l}\text { Stage } 1 \\
\text { Broken }\end{array}$ & $\begin{array}{c}\text { Stage } 2 \\
\text { Financial } \\
\text { reporting } \\
\text { driven }\end{array}$ & $\begin{array}{c}\text { Stage } 3 \\
\begin{array}{c}\text { Customized / } \\
\text { stand-alone }\end{array}\end{array}$ & $\begin{array}{c}\text { Stage } 4 \\
\text { Integrated }\end{array}$ & $\begin{array}{l}\text { Stage } 5 \\
\text { Decision } \\
\text { Support }\end{array}$ \\
\hline $\begin{array}{r}\text { Data } \\
\text { Quality }\end{array}$ & $\begin{array}{l}\text { - Many errors } \\
\text { - large variances }\end{array}$ & $\begin{array}{l}\text { - No surprise } \\
\text { - meets audit } \\
\text { standards }\end{array}$ & $\begin{array}{l}\text { - Shared databases } \\
\text { - stand-alone systems } \\
\text { - informal linkages }\end{array}$ & $\begin{array}{l}\text { - Fully linked } \\
\text { databases and } \\
\text { systems }\end{array}$ & $\begin{array}{l}\text { - Fully linked } \\
\text { databases and } \\
\text { systems }\end{array}$ \\
\hline $\begin{array}{r}\text { External } \\
\text { Financial } \\
\text { Reporting }\end{array}$ & - Inadequate & $\begin{array}{l}\text { - tailored to } \\
\text { financial } \\
\text { reporting need }\end{array}$ & $\begin{array}{l}\text { - Stage } 2 \text { System for } \\
\text { financial transactions } \\
\text { and periodic } \\
\text { reporting }\end{array}$ & $\begin{array}{l}\text { - financial reporting } \\
\text { systems }\end{array}$ & $\begin{array}{l}\text { - financial reporting } \\
\text { systems }\end{array}$ \\
\hline $\begin{array}{r}\text { Product/ } \\
\text { Customer } \\
\text { Costs }\end{array}$ & - Inadequate & $\begin{array}{l}\text { - inaccurate } \\
\text { - hidden costs } \\
\text { and profits }\end{array}$ & $\begin{array}{l}\text { - PC-based ABC } \\
\text { models }\end{array}$ & $\begin{array}{l}\text { - integrated } \mathrm{ABC} / \mathrm{M} \\
\text { systems }\end{array}$ & $\begin{array}{l}\text { - integrated } \mathrm{ABC} / \mathrm{M} \\
\text { systems } \\
\text { - predictive costing }\end{array}$ \\
\hline $\begin{array}{r}\text { Operational/ } \\
\text { Strategic } \\
\text { Control }\end{array}$ & - Inadequate & $\begin{array}{l}\text { - financial } \\
\text { feedback only } \\
\text { •delayed/ } \\
\text { aggregated }\end{array}$ & $\begin{array}{l}\text { - Kaizan costing; } \\
\text { pseudo profit centers, } \\
\text { timely non-financial }\end{array}$ & $\begin{array}{l}\text { - Operational \& } \\
\text { Strategic } \\
\text { Performance } \\
\text { measurement } \\
\text { systems }\end{array}$ & $\begin{array}{l}\text { - Operational \& } \\
\text { Strategic predictive } \\
\text { scenario } \\
\text { - links to scorecards }\end{array}$ \\
\hline
\end{tabular}

Source: Cokins, 2001. The upgrade of the four-phase cost system development by Cooper \& Kaplan (1991)

Within our research, we asked a series of questions for each criterion, which, in the end, represent the level of development of an individual criterion. Enterprise classification by level of cost system development, by all four criteria, we have conducted using the Artificial Neural Networks -ANN. It is an adaptive statistical model for data processing inspired by structure and activity of a biological nervous system. ANN has conducted mapping between input-output from connections that have been presented to them in sets of data during training of the network. These sets of data have included a matrix of 200 possible variations in given answers, classified by levels of cost system development. We created a feedforwardnet neural network with 20 neurons in the hidden field. Classification of data for training, validation and testing is random. The network uses $60 \%$ of data for training, and $20 \%$ for validation and $20 \%$ for testing. When training, the network uses Levenberg-Marquardt algorithm, and it works through Mean Squared Error method. Lavenberg-Marquardt algorithm serves for finding optimal solution of an overdetermined system of non-linear equations in the last-square sense. Following the results, we used oneway analysis of variance (ANOVA) to test the difference in the number of SMA techniques used and the level of development of the cost system. 


\section{Research results and discussion}

\subsection{Prevalence of SMA techniques}

The results of the research on the representation of certain SMA techniques are presented in Table 1. The research shows that the three most common SMA techniques in large BiH companies are: Quality Costing (52.73\%), Strategic Pricing (51.82\%) and Benchmarking $50.91 \%$, while the least represented techniques are: Life Cycle Costing (11.82\%), Attribute Costing and Integrated Performance Management Systems (with 12.73\% each), and Activity Based Costing/ Management (17.27\%).

Table 1. Prevalence of SMA techniques

\begin{tabular}{|l|r|r|}
\hline \multicolumn{1}{|c|}{ Management accounting methods } & No of companies & $\begin{array}{c}\text { \% in } \\
\text { sample }\end{array}$ \\
\hline Activity Based Costing & 19 & 17.27 \\
\hline Attribute Costing & 14 & 12.73 \\
\hline Benchmarking & 56 & 50.91 \\
\hline Competitive Position Monitoring & 45 & 40.91 \\
\hline Competitor Cost Assessment & 34 & 30.91 \\
\hline Competitor Performance Appraisal on public financial statements & 23 & 20.91 \\
\hline Customer-focused Accounting & 35 & 31.82 \\
\hline Integrated Performance Management Systems & 14 & 12.73 \\
\hline Life Cycle Costing & 13 & 11.82 \\
\hline Quality Costing & 58 & 52.73 \\
\hline Strategic Costing & 52 & 47.27 \\
\hline Strategic Pricing & 57 & 51.82 \\
\hline Value Chain Costing & 22 & 20.00 \\
\hline
\end{tabular}

Source: Authors' processing

The participation of certain SMA techniques in $\mathrm{BiH}$, the presence of SMA techniques indicates the struggle for survival in the market through quality management and strategic pricing with corrective actions resulting from observation and comparison with competitors. In general, large companies in $\mathrm{BiH}$ use only four SMA techniques on average (Table 2).

Table 2. Descriptive statistics on SMA techniques used

\begin{tabular}{|l|r|r|r|r|r|r|}
\hline \multicolumn{1}{|c|}{ Sectors } & \multicolumn{1}{c|}{ n } & \multicolumn{1}{c|}{ F } & Average & Min & Max & St.Dev \\
\hline Manufacturing & 47 & 210 & 4.468 & 1 & 10 & 1.282 \\
\hline Merchandising & 33 & 139 & 4.212 & 1 & 8 & 1.916 \\
\hline Services & 30 & 93 & 3.100 & 1 & 7 & 1.373 \\
\hline Total & 110 & 442 & 4.018 & & & 1.524 \\
\hline
\end{tabular}

Source: author's processing

Companies in the field of manufacturing industry, which are in the sample structure and the most numerous, have the highest value of the frequency of use of various SMA techniques, and the average number of techniques used of 4.47. On the other hand, the 
lowest number of used SMA techniques is recorded in the service sector, where the total frequency of used techniques is 93 , and the average number of used techniques is 3.1 .

\subsection{Analysis of the dependence of the number of applied SMA techniques and the level of development of the cost system}

According to the methodology for assessing the degree of development of cost systems in $\mathrm{BiH}$ companies, in a sample of 110 companies we had that $58.18 \%$ of them belong to the second level of cost system development, $28.18 \%$ to the third level of cost system development and $13.64 \%$ have the first level of cost system development. There were no companies in the sample with the fourth and fifth level of cost system development.

One-way analysis of variance (ANOVA) tested the differences in the number of users of SMA techniques applied by companies and identified three levels of development of enterprise cost systems in the sample. Companies that applied on average two techniques of SMA belonged to the first level of development, while the second level of development belonged to companies that applied on average four techniques of SMA. On average, six techniques were applied by companies that belonged to the third level of development of the cost system. The differences are statistically significant with a probability of $\mathrm{p}<0.000$ $(\mathrm{F}=8.270)$, which is shown in Table 3. Based on the results we can say that companies that apply a number of SMA techniques have a higher level of cost system development in the company, and vice versa (Graph 1).

Table 3. Average number of SMA techniques according to the levels of development of the cost system

\begin{tabular}{|l|c|c|c|c|c|cc|}
\hline & $\mathrm{n}$ & Mean & $\mathrm{SD}$ & \multicolumn{2}{|c|}{ 95\% CI for Mean } & \multicolumn{2}{l|}{} \\
\cline { 5 - 8 } & & & & Lower Bound & Upper Bound & $\mathrm{F}$ & $\mathrm{p}$ \\
\hline First level & 15 & 2.00 & 2.24 & 0.76 & 3.24 & & \\
\hline Second level & 64 & 4.08 & 3.31 & 3.25 & 4.91 & 8.270 & 0.000 \\
\hline Third level & 31 & 5.65 & 2.11 & 4.87 & 6.42 & & \\
\hline
\end{tabular}

Mean-arithmetic mean, $\boldsymbol{S D}$-standard deviation, $\boldsymbol{n}$-sample size, 95\% $\boldsymbol{C I}$-confidence interval for arithmetic mean with $95 \%, \boldsymbol{F}$-Fisher F test (ANOVA), p-probability of rejecting the null hypothesis with a risk of 5\% 
Graph 1. Positions of the average number of accounting instruments and techniques according to the stages of development of the accounting system

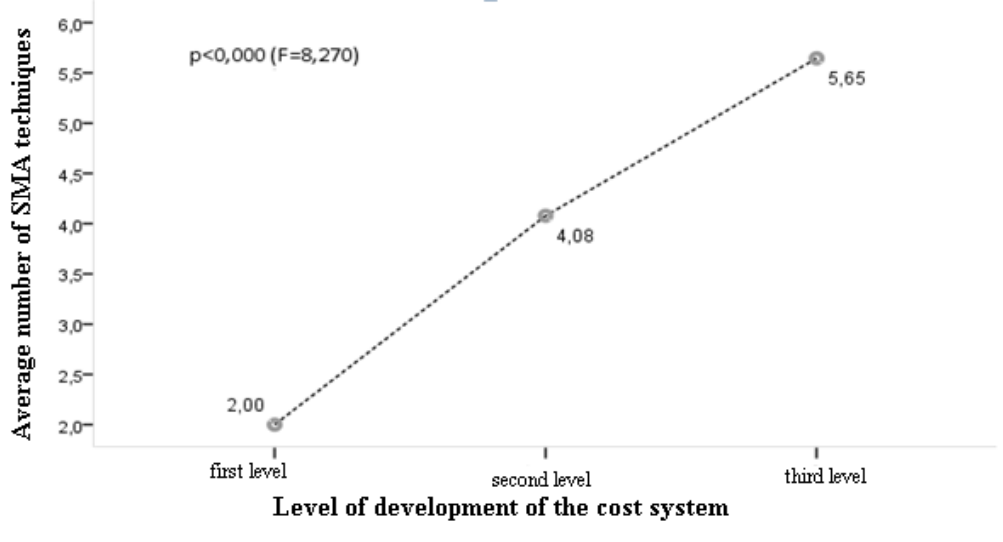

Source: author's processing

Looking at the trend line, it is to be expected that companies that have higher levels of development of the accounting cost system also have a more developed management accounting function and use a larger number of tools and techniques in the process of creating accounting information.

\section{Conclusion}

Based on the conducted research, the most common techniques of SMA in large companies in $\mathrm{BiH}$ are: Quality Costing (52.73\%), Strategic Pricing (51.82\%) and Benchmarking (50.91\%), while the least common techniques are: Life Cycle Costing (11.82\%), Attribute Costing and Integrated Performance Management Systems (12.73\% each), and Activity Based Costing/ Management (17.27\%). On average, all companies in the sample use 4 SMA techniques, with the average number of techniques used in manufacturing companies 4.47 , in merchandising companies 4.21 , while in the service sector it is 3.1 .

Companies that applied on average two techniques of SMA belonged to the first level of development, those that applied on average four techniques belonged to the second level of development, while companies that have the third level of cost system development on average applied six techniques of SMA. There were no companies in the sample with the fourth and fifth level of cost system development.

In future research, it would be good to do a regional survey on the levels of development of cost systems in companies by different sizes and industries to which they belong, the frequency of use of certain techniques of SMA and selected market positioning strategies. It is recommended to compare the dependence of these variables at the level of the countries of Southeast Europe. A similar research study has never been conducted before. 


\section{References}

Akenbor, C. \& Okoye, E (2012). The adoption of strategic management accounting in Nigerian manufacturing firms. AFRREV IJAH: An International Journal of Arts and Humanities, 1(3), 270-287.

Bensaou, M., \& Venkatraman, N. (1995). configurations of interorganizational relationships: a comparison between U.S. and Japanese automakers. Management Science, 41, 1471-1492. Doi: https://doi.org/10.1287/mnsc.41.9.1471

Bromwich, M., \& Bhimani, A. (1994). Management Accounting: Pathways to Progress. London: The Chartered Institute of Management Accountants.

Bromwich, M. (1996). Strategic Management Accounting in Management Accounting Handbook. In: Drury, C. (Ed). The Chartered Institute of Management Accountants, pp.203-227.

Bromwich, M., \& Bhimani, A. (1989). Management Accounting: Evolution not Revolution. London: The Chartered Institute of Management Accountants.

Chartered Institution for Managerial Acountants (CIMA) (2015). Management accounting in Support of the Strategic Management process. Available at: https:/www.cimaglobal.com/Research--Insight/Management-accounting-in-support-of-thestrategic-management-process/ (Accessed on 04/10/2020)

Cinquini, L., \& Tenucci, A. (2010). Strategic management accounting and business strategy: a loose coupling?. Journal of Accounting \& Organizational Change, 6(2), 228259. Doi: https://doi.org/10.1108/18325911011048772

Cokins, G. (2001). Activity-Based Cost Management. USA: John Wiley \&Sons, Inc.

Cooper, R., \& Kaplan, R. (1991). The Design of Cost Management Systems, 2ed. USA: Prentice Hall, Inc.

Drury, C. (2008). Management and Cost Accounting. 7-th ed. UK: Path Bond.

Gadžo, A., \& Lalić, S. (2019). Researching impact of cost system genesis on profitability level of manufacturing enterprises. In Šimurina, Načinović Braje, Pavić (Eds.), Proceedings of FEB Zagreb 10th International Odyssey Conference on Economics and Business, pp.570-583. https://doi.org/10.22598/odyssey/2019.1

Janjić, V. (2006). Strategijsko upravljačko računovodstvoi balansna karta rezultata. Ekonomski horizonti, 1-2, 113-133.

Kaplan, R. S., \& Norton, D. P. (1992). The balanced scorecard: measures that drive performance. Harvard Business Review, 71-79.

Marlin, D., Ketchen, D.J., \& Lamont, B. (2007). Equifinality and the strategic groups - performance relationship. Journal of Managerial Issues, 19(2), 208-232. 
Miles, R.E., Snow, C.C., Meyer, A.D., \& Coleman, H.J. (1978). Organizational strategy, structure and process. New York:McGraw-Hill.

Milićević, V. (2003). Strategijsko upravljačko računovodstvo. Beograd: Ekonomski fakultet - Centar za izdavačku delatnost.

Puškarević, S., \& Gadžo, A. (2014). (Dys) functionality of accounting cost systems in manufacturing companies of Tuzla canton. Ekonomski vjesnik, 27(2), 409-422.

Ramljak \& Rogošić (2012). Strategic management accounting practices in Croatia. The Journal of International Management Studies, 7(2), 93-100.

Roslender, R. (1995). Accounting for strategic positioning: responding to the crisis in management accounting. British Journal of Management, 6(1), 45-57. Doi: https://doi.org/10.1111/j.14678551.1995.tb00085.x

Puškarević, S., \& Gadžo, A. (2014b). Place of accounting information in business decision making within Tuzla Canton companies. TEM Journal, 3(1), 68.

Shank, J. K. (1989). Strategic cost management: new wine or just new bottles. Journal of Management Accounting Research, 1, 47-65. Available at: https://www.academia.edu/956538/Strategic_cost_management_new_wine_or_just_new b ottles (accessed on $1^{\text {st }}$ February 2020).

Short, J.C., Payne G.T., \& Ketchen D.J. (2008). Research on organizational configurations: past accomplishments and future challenges. Journal of Management, 34(6), 1053-1080. Doi: https://doi.org/10.1177\%2F0149206308324324

Simmonds, K. (1981). Strategic management accounting, Management Accounting, 59(4), 26-29. 